\title{
An Electrophysiological Correlate of Protein Kinase C Isozyme Distribution in Cultured Cerebellar Neurons
}

\author{
David J. Linden, ${ }^{a}$ Michelle Smeyne, Shaiu C. Sun, and John A. Connor \\ Department of Neurosciences, Roche Institute of Molecular Biology, Roche Research Center, Nutley, New Jersey 07110
}

\begin{abstract}
Protein kinase $C$ (PKC) is a family of at least seven closely related molecules (isozymes) that vary in terms of their requirements for activation and their distribution among cells of the brain. A striking example of this differential distribution is seen in the cerebellum, where Purkinje cells express PKC$\mathrm{I}$, an isozyme that is strongly activated by both phorbol ester (PE), and low doses of cis-unsaturated fatty acid (c-UFA), while granule cells predominantly express PKC-II, an isozyme that is strongly activated by PE but not $c$-UFA. Both Purkinje and granule cells have large, easily recorded voltage-gated $K$ currents. These currents are attenuated by PKC activators in several other varieties of neuron. We hypothesized that the effects of these two PKC activators would be predicted by the distribution of the relevant PKC isozyme, and that the delayed outward rectifier current, $l_{k}$, would be attenuated by both PE and c-UFA in Purkinje cells, but only by $P E$ in granule cells. This hypothesis was confirmed in perforated-patch recordings. The attenuation produced by both activators could be blocked by application of a specific PKC inhibitor, RO-31-8220, and could not be mimicked by inert forms of PE or c-UFA. To our knowledge, this study represents the first report of an electrophysiological correlate of PKC isozyme distribution.
\end{abstract}

Protein kinase $\mathrm{C}(\mathrm{PKC})$ is found in high concentration in neural tissues and has been implicated in a broad spectrum of neuronal functions including process outgrowth, neurotransmitter release, synaptic plasticity, and the regulation of ion channels (Nishizuka, 1988; Linden and Routtenberg, 1989a; Malinow et al., 1989; Olds et al., 1989; Shearman et al., 1989b; Linden and Connor, 1991). It has been appreciated for several years that PKC is a family of isozymes (Coussens et al., 1986; Knopf et al., 1986; Ono et al., 1987) with different patterns of distribution in the brain as revealed by immunocytochemical (Ase et al., 1988; Hashimoto et al., 1988; Hidaka et al., 1988; Huang ct al., 1988, 1990; Kose et al., 1988; Saito et al., 1988; Shimohama et al., 1990) or mRNA hybridization techniques (Brandt et al., 1987; Young, 1988). However, functional correlates of this differential distribution have been difficult to determine.

PKC was originally described as a Ca- and phospholipiddependent enzyme activated by a diacylglycerol (DAG) second messenger produced by phosphoinositide hydrolysis (Kikkawa

\footnotetext{
Received Feb. 17, 1992; revised Mar. 30, 1992; accepted Apr. 7, 1992.

We thank Dr. James Morgan, Dr. Michael Dickinson, and Dr. Karl Schilling for their valuable suggestions.

Correspondence should be addressed to John A. Connor at the above address.

“ Present address: Department of Neuroscience, The Johns Hopkins University School of Medicine, 725 North Wolfe Street, Baltimore, MD 21205.

Copyright $\odot 1992$ Society for Neuroscience $0270-6474 / 92 / 123601-08 \$ 05.00 / 0$
}

et al., 1982). The DAG activation pathway may be mimicked experimentally by addition of phorbol ester (PE), and has been shown to activate all PKC isozymes studicd to date. Morc recently, a second activation pathway has been demonstrated in which cis-unsaturated fatty acids (c-UFAs) such as oleate and arachidonate activate PKC (McPhail et al., 1984) in the absence of $\mathrm{Ca}$ and phospholipid (Murakami and Routtenberg, 1985; Murakami et al., 1986).

This second pathway of activation is largely restricted to the PKC-I isozyme as demonstrated in purified PKC preparations made from cerebellar tissue. Shearman et al. (1989a) separated PKC activity from bovine cerebellum into three fractions by hydroxyapatite column chromatography. These fractions, called PKC-I, -II, and -III, correspond to the products of the $\gamma, \beta-\mathrm{I} /$ $\beta$-II, and $\alpha$ PKC genes, respectively. The greatest activation of PKC-I was achieved with $12 \mu \mathrm{M}$ arachidonate $(\sim 55 \%$ of maximal stimulation produced with phosphatidyl serine/diolein/ calcium). PKC-II and PKC-III were almost entirely inert with respect to arachidonatc stimulation, bcing activated at $\sim 7 \%$ and $10 \%$ of maximum, respectively, by $50 \mu \mathrm{M}$ arachidonate (the highest concentration reported). As the present study was conducted in living cells with intact metabolic machinery, we chose to use oleic acid $(\mathrm{OA})$ rather than arachidonate to allow for the separation of effects produced by direct PKC activation from those produced by arachidonate metabolites (Wolfe, 1982; Needleman et al., 1986).

Activation of PKC by PE or DAG has been shown to attenuate voltage-dependent $\mathrm{K}$ currents in several types of neuron (Baraban et al., 1985; Farley and Auerbach 1986; Higashida and Brown, 1986; Malenka et al., 1986; Grega et al., 1987; Apkon and Nerbonne, 1988; Colby and Blaustein, 1988; Doerner et al., 1988; Sawada et al., 1989). The Purkinje and granule cells of the cerebellum show well-developed voltage-gated $\mathrm{K}$ currents, including the delayed outward rectifier current, $I_{\mathrm{K}}$. In addition, Purkinje cells strongly express PKC-I, whilc granulc cells do not express this isozyme (Brandt et al., 1987; Ase et al., 1988; Hashimoto et al., 1988; Hidaka et al., 1988; Huang et al., 1988, 1990; Kose et al., 1988; Saito et al., 1988; Young, 1988; Shimohama et al., 1990). Hence, these two cell types serve as an ideal model system in which to test the hypothesis that PKC isozyme distribution predicts the electrophysiological response of neurons to different pathways of PKC activation.

\section{Materials and Methods \\ Cell culture}

Cultured cerebellar neurons were prepared by a modification of the method of Hockberger et al. (1989b). Timed-pregnant rats were anesthetized with ether and the fetuses were removed. Cerebella were dissected, pooled, and chopped into $\sim 1 \mathrm{~mm}$ chunks in ice-cold phosphatebuffered saline (PBS). The chunks were digested for $5 \mathrm{~min}$ at room 


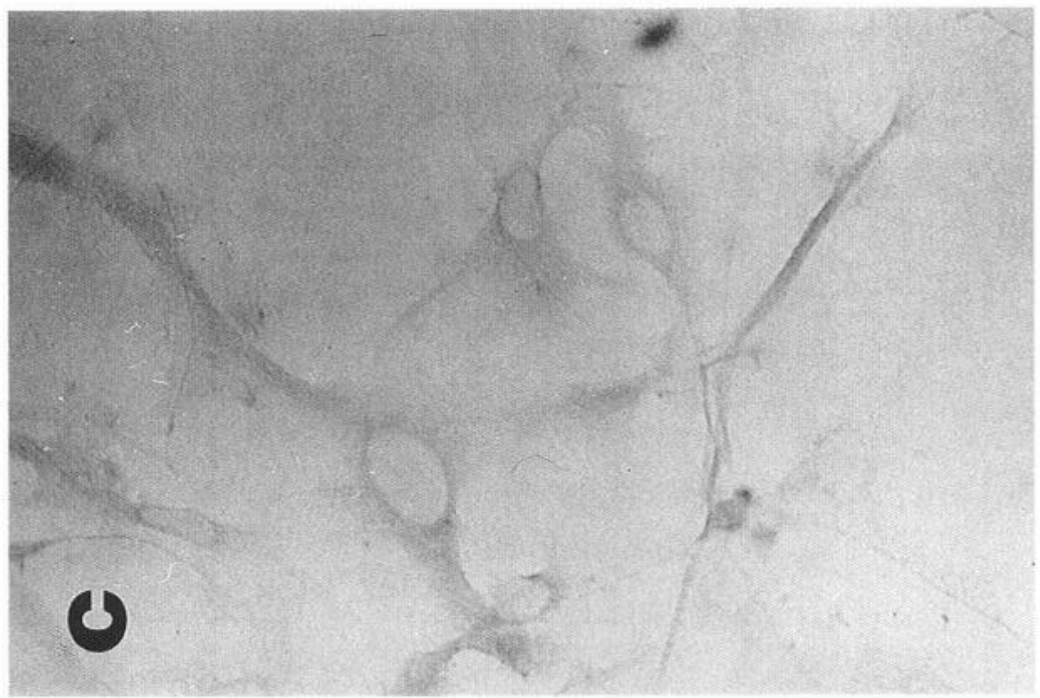

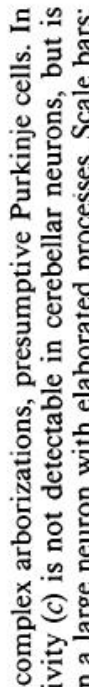

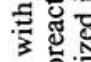

릉

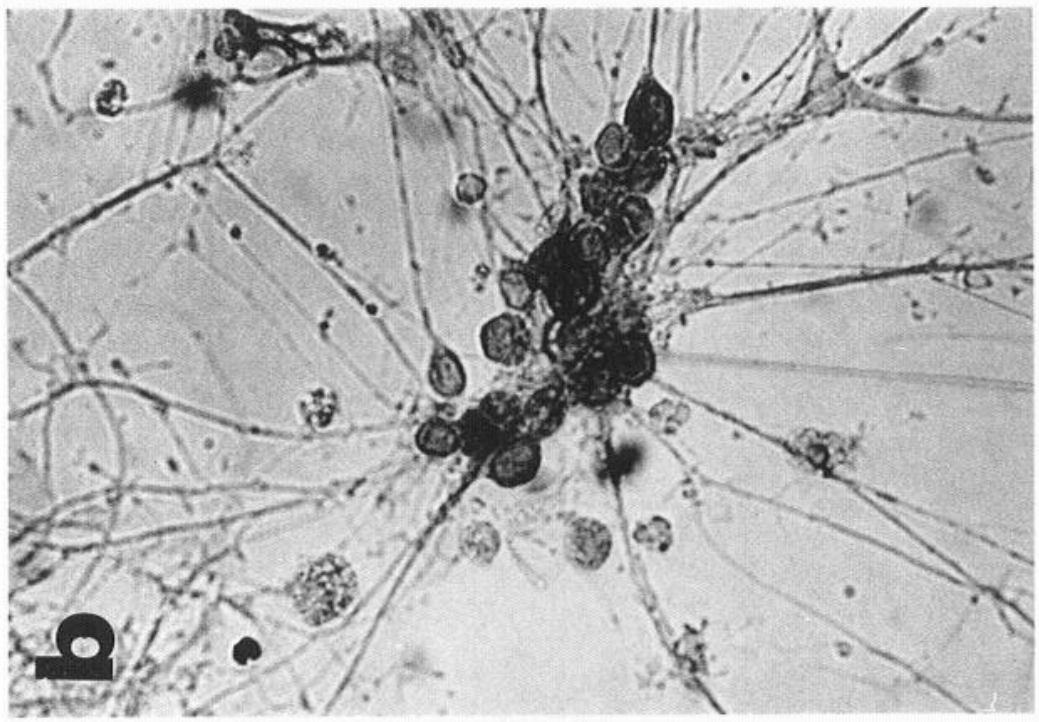

品 둥

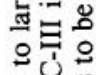

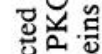
密完运 $\approx$ 象 ब्र

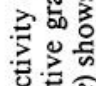
히 总 卷完 E. ง ․ㅡㄹ

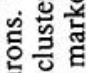
啳 홀. 递熍

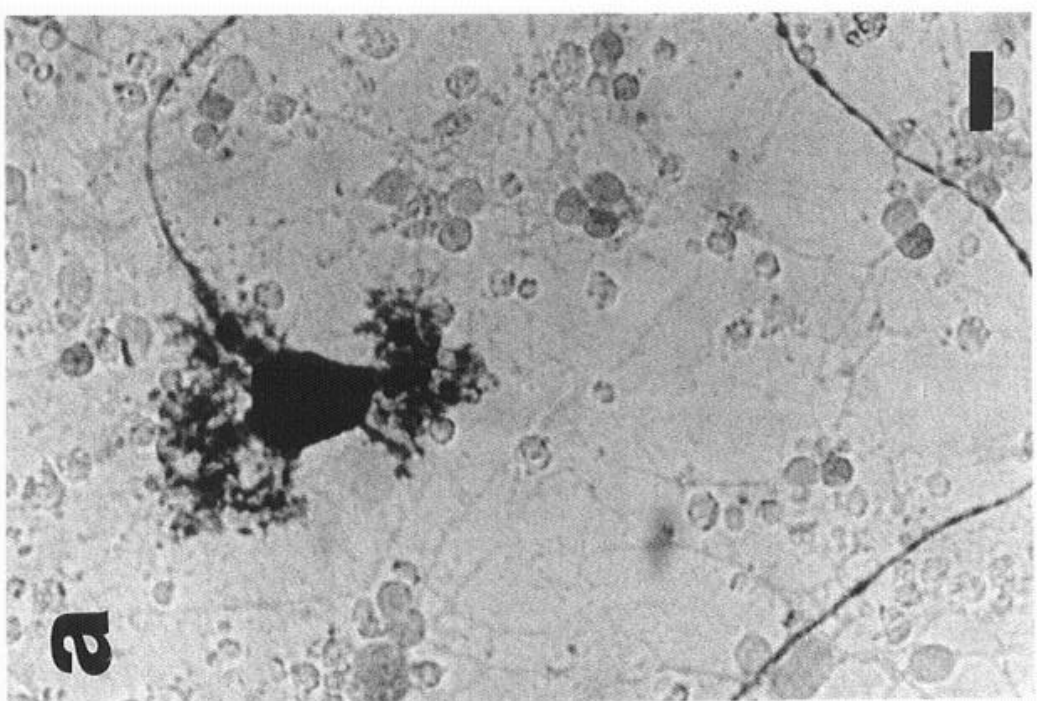

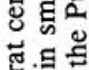

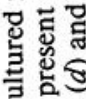
ठิ. .

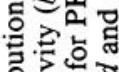
E. 路 동 든으 당 U⿳亠二口犬 점 i. 我艺 今气 

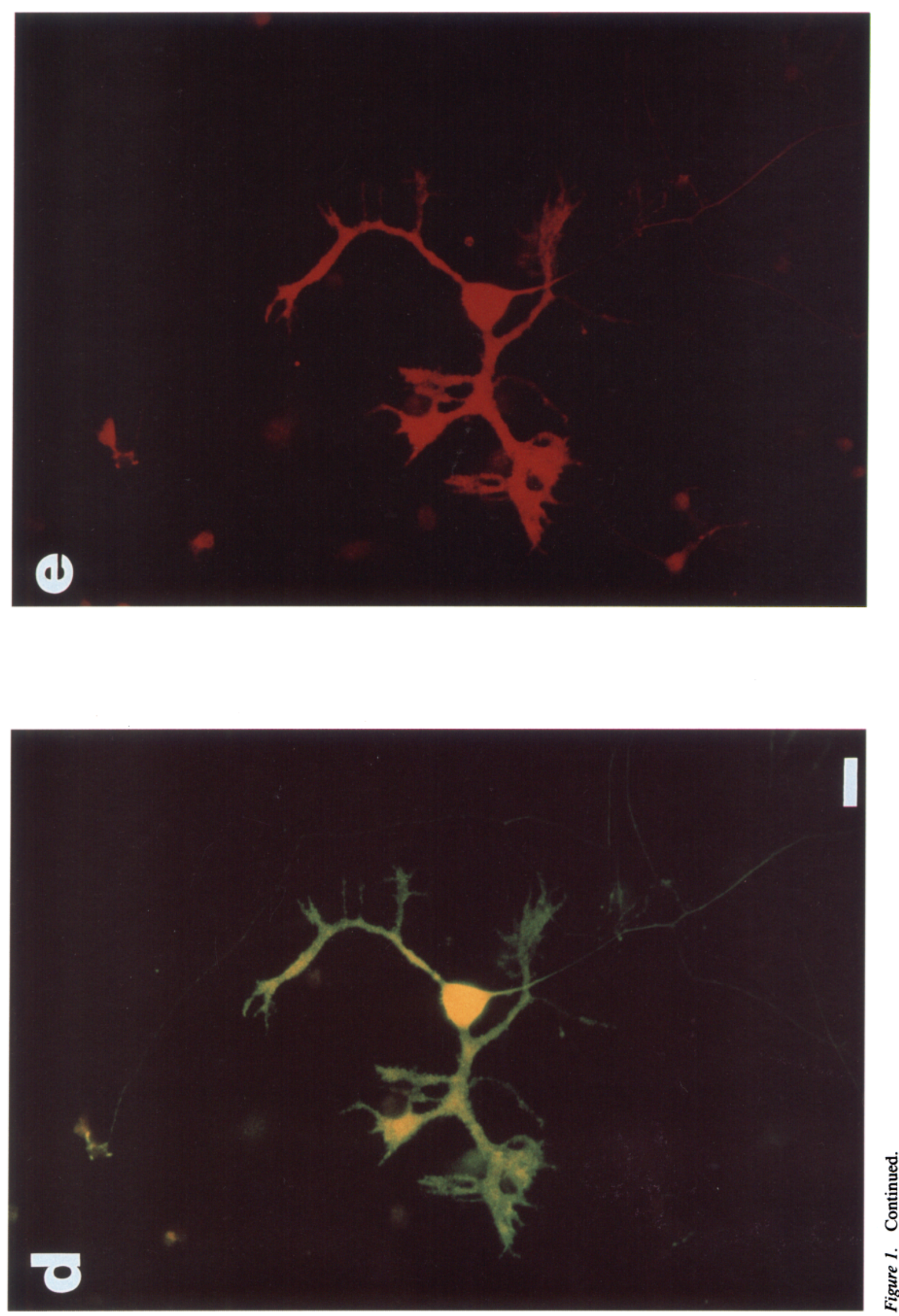


\section{PDB $100 \mathrm{nM}$}
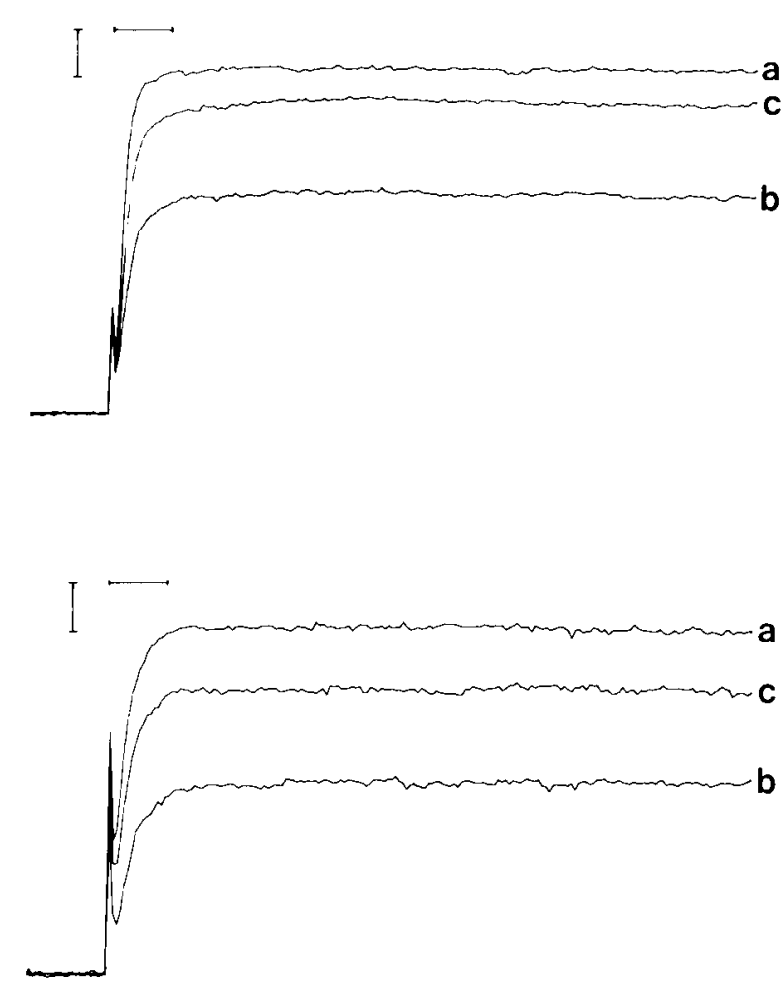

\section{$\mathrm{OA} 20 \mu \mathrm{M}$}
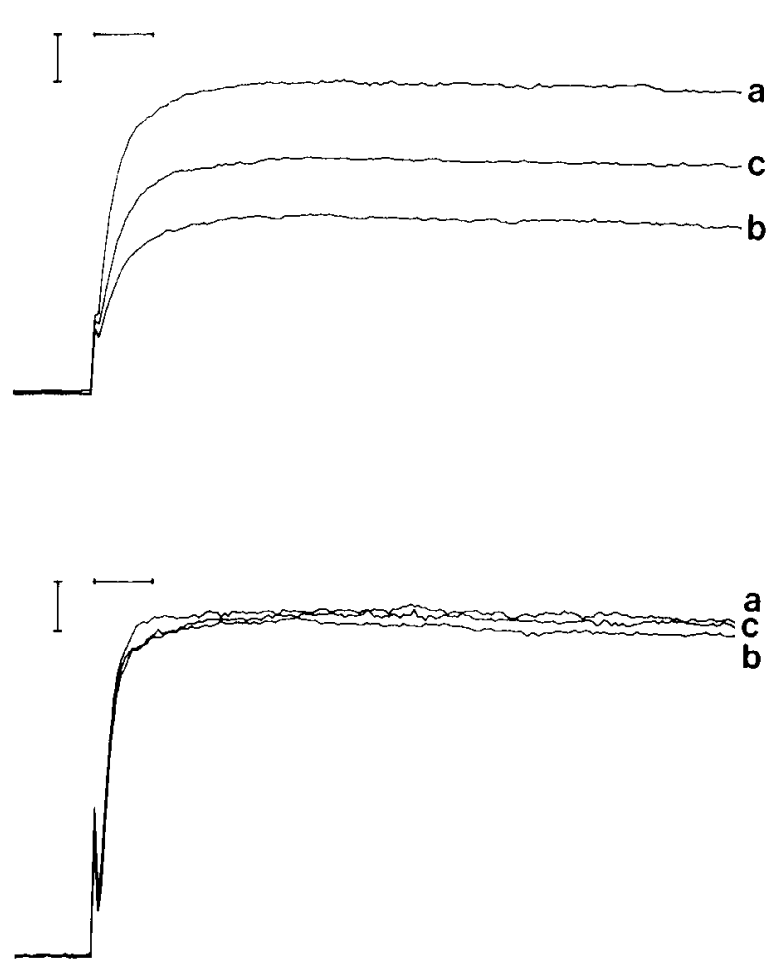

Figure 2. Effects of a PE and a c-UFA on $I_{\mathrm{K}}$ in cultured granule and Purkinje cells. $I_{\mathrm{K}}$ was elicited by a step from $-30 \mathrm{mV}$ to $+30 \mathrm{mV}$ in TTXcontaining, nominally $\mathrm{Ca}^{2+}$-free saline. $I_{\mathrm{K}}$ was attenuated by both classes of PKC activator in Purkinje cells $(P C)$. However, in granule cells $(G C)$, PE produced attenuation but c-UFA was without effect. Labels on current traces are as follows: $a$, control trace, immediately prior to application of test compound; $b$, test trace, 15 min after application of test compound; $c$, washout trace, $10-14$ min after beginning of washout. Calibration: $100 \mathrm{pA}, 8 \mathrm{msec}$.

temperature $\left(20-23^{\circ} \mathrm{C}\right)$ in PBS containing $0.4 \%$ trypsin (type XI, Sigma, St. Louis, MO) and $0.5 \%$ DNase I (type IV, Sigma). Following digestion, the chunks were washed twice in PBS with $10 \%$ fetal calf serum and 12 $\mathrm{mM} \mathrm{MgSO}_{4}$ for $2 \mathrm{~min}$, and twice again in the same solution without trypsin inhibitor. The chunks were then triturated with a fire-polished Pasteur pipette ( $\sim 0.5 \mathrm{~mm}$ tip diameter) in PBS with $0.5 \%$ DNase I until the cells were completely dispersed (about 15 passages). The cell suspension was spun at $500 \times g$ for $10 \mathrm{~min}$, following which the pellet was resuspended at a concentration of $5 \times 10^{5} \mathrm{cells} / \mathrm{ml}$ in a growth medium containing Minimal Essential Medium (MEM) with Earle's salts (GIB$\mathrm{CO}$, Grand Island, NY) and supplemented with $6.0 \mathrm{gm} /$ liter glucose, $3.7 \mathrm{gm} /$ liter $\mathrm{NaHCO}_{3}, 2 \mathrm{mM}$ glutamine, $25 \mathrm{mM} \mathrm{KCl}$ (final concentration), N3 supplement (Romijn et al., 1982), $200 \mathrm{U} / \mathrm{ml}$ penicillin $\mathrm{G}$ (GIBCO), $200 \mu \mathrm{g} / \mathrm{ml}$ streptomycin (GIBCO), and $10 \%$ heat-inactivated horse serum (GIBCO). Cells were plated on glass coverslips coated with poly-D-lysine (Sigma) and were maintained in a humidified atmosphere containing $10 \% \mathrm{CO}_{2}$ at $37^{\circ} \mathrm{C}$. Twenty-four hours after plating, the penicillin, streptomycin, and serum were withdrawn. Following this, cells were fed two or three times per week. In some cultures, $100 \mu \mathrm{M}$ cytosine$\beta$-D-arabinofuranoside $\mathrm{HCl}$ (Sigma) was added at the time of the second or third feeding.

\section{Immunocytochemistry}

Single-labeled cells. Cells were briefly rinsed with PBS and then fixed in $4 \%$ formaldehyde in PBS buffer for $15 \mathrm{~min}$. Cells were then washed in $10 \%$ methanol, $0.3 \% \mathrm{H}_{2} \mathrm{O}_{2}$ to saturate endogenous peroxidase activity, permeabilized with $0.1 \%$ Triton $X-100$, and blocked with $5 \%$ normal goat serum prior to application of the primary antibodies. Mouse monoclonal antibodies directed against PKC isozymes I, II, and III (produced by the method of Hidaka et al., 1988) were purchased from Seikagaku America (Rockville, MD) and were applied at a dilution of $1: 75$, over- night at $4^{\circ} \mathrm{C}$. Immunoreactivity for a single isozyme was visualized using the anti-mouse IgG Vectastain ABC kit (Vector Labs, Burlingame, CA) with 3,3'-diaminobenzidine as the substrate for HRP bound to the secondary antibody (e.g., see Fig. $1 a-c$ ). To reduce cross-reactivity betwcen the anti-mouse secondary antibody and the cells from rat, $2 \%$ normal rat serum was used as a blocking agent.

Double-labeled cells. Cells were fixed, permeabilized, and blocked as above. The cultures were incubated overnight at $4^{\circ} \mathrm{C}$ in a mixture of two primary antisera: a mouse monoclonal antiserum directed against calbindin- $\mathrm{D}_{28 \mathrm{~K}}$ (Sigma) at 1:500 and a rabbit polyclonal antiserum directed against a synthetic oligopeptide from the variable region of PKC-I (GIBCO/Bethesda Research Laboratories) at 1:800. Following thorough washing, the cells were incubated in fluorescein-conjugated anti-mouse $\operatorname{IgG}$ at $1: 75$ for $60 \mathrm{~min}$, biotinylated anti-rabbit IgG (Vector) at 1:500 for $30 \mathrm{~min}$, and avidin-Texas Red ( $\mathrm{pH} 8.2$, Vector) at 1:250 for $60 \mathrm{~min}$. All the secondary reactions were performed at room temperature, in the dark, with $5 \times$ washing in PBS between each step. Cells were mounted in glycerol with $5 \%$ propyl gallate and observed on a Zeiss Axioplan microscope (e.g., see Fig. 1d,e).

\section{Electrophysiology}

Perforated-patch recording was performed according to the method of Horn and Marty (1987). Patch electrodes were pulled from N51A glass (1.65 mm o.d., $1.20 \mathrm{~mm}$ i.d.; Garner Glass Co., Claremont, CA) and polished on a microforge to yield a resistance of $1-2 \mathrm{M} \Omega$ when recorded with normal internal and external solutions (see below). We used a List EPC-7 patch-clamp amplifier and membrane capacitance neutralization was optimized. Membrane currents were filtered at $3 \mathrm{kHz}$, digitized with a 12-bit $\mathrm{A} / \mathrm{D}$ converter operating at a sampling frequency of 20 $\mathrm{kHz}$, and stored on the hard disk of an LSI-11/23 computer for later analysis. Linear leakage current was determined by hyperpolarizing 
PDB 100nM
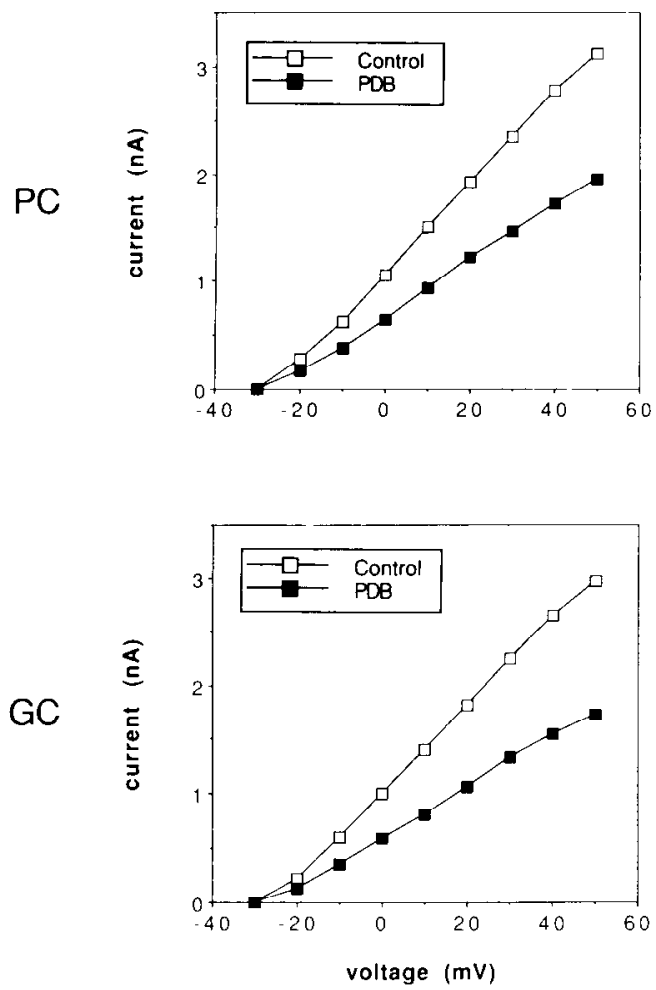

OA $20 \mu \mathrm{M}$
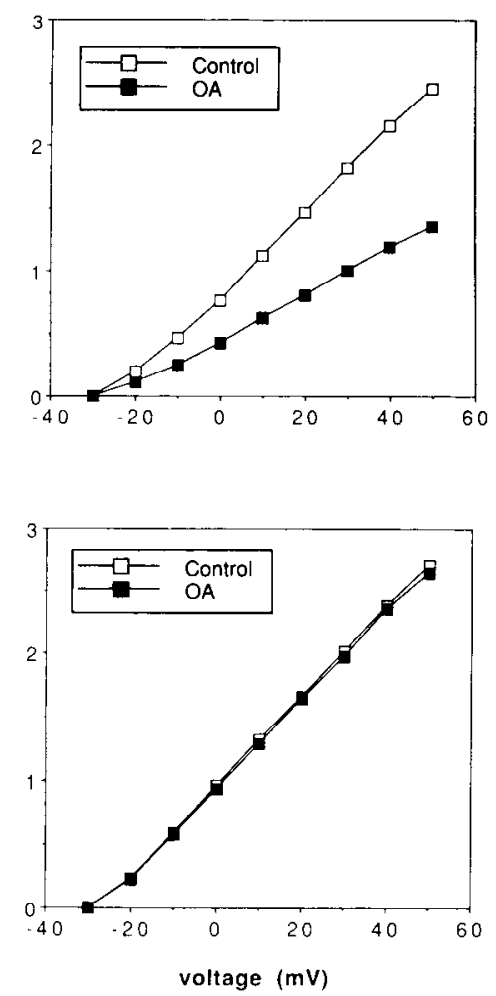

Figure 3. Current-voltage relations of $I_{\mathrm{K}}$ during application of a PE and a c-UFA to cultured cerebellar neurons. Families of currents were elicited by depolarizing steps from a holding potential of $-30 \mathrm{mV}$. The current was measured at the point of greatest positivity, $15 \mathrm{~min}$ after drug application. In the three cases in which an attenuation of $I_{\mathrm{K}}$ was observed, it took the form of a decrease in slope conductance without alteration in the voltage dependence of activation. Current-voltage relations shown are from single neurons, representative of a sample of $n=6$ /group. $P C$, Purkinje cells; $G C$, granule cells. command pulses and was digitally subtracted from current records. The recording electrodes were filled with a solution containing (in $\mathrm{mM}$ ) $\mathrm{K}_{2} \mathrm{SO}_{4}, 95 ; \mathrm{KCl}, 15 ; \mathrm{MgCl}_{2}, 8$; and HEPES, $10 ; \mathrm{pH} 7.35$ with $\mathrm{KOH}$. The cells were bathed in a solution containing $\mathrm{NaCl}, 150 ; \mathrm{KCl}, 5 ; \mathrm{MgCl}_{2}$, 0.8; HEPES, 10; glucose, 10; TTX, 0.005; and picrotoxin, 0.01, pH 7.35 with $\mathrm{NaOH}$, that flowed at a rate of $3 \mathrm{ml} / \mathrm{min}$ (bath vol, $1.5 \mathrm{ml}$ ). For perforated-patch recording, nystatin (Sigma) was added to the internal saline to achieve a final concentration of $250 \mu \mathrm{g} / \mathrm{ml}$ in $0.5 \%$ dimethyl sulfoxide. However, a small amount of nystatin-free solution was used to fill the tip of the recording pipette to facilitate a seal formation. Typically, a 20 min waiting period was required after gigaseal formation to achieve stable $I_{\mathrm{K}}$ recordings. Conventional whole-cell recordings were made using the same electrodes, external saline, and recording equipment detailed above. The internal saline contained (in $\mathrm{mM}$ ) $\mathrm{KCl}, 140$; EGTA , 11; $\mathrm{CaCl}_{2}, 1$; HEPES, 10; and Mg-ATP, 2. In choosing cells for recording, care was taken to select those that most completely fit the morphological profile of a given cell type. Only small (soma diameter, $<10 \mu \mathrm{m}$ ), round, clustering cells were selected for granule cell recording, and only large (soma diameter, $>25 \mu \mathrm{m}$ ) cells with complex dendritic arborizations were selected for Purkinje cell recording. When recordings were made from the latter cells in current-clamp mode, with $2 \mathrm{mM}$ $\mathrm{Ca}^{2+}$ present in the external saline, these neurons showed spontaneous $\mathrm{Ca}^{2+}$ spiking typical of Purkinje cells. Only cells with resting potentials less than $-50 \mathrm{mV}$ and $I_{\mathrm{K}}$ that remained stable for at least $10 \mathrm{~min}$ prior to drug application were used. Experiments were performed at $20-24^{\circ} \mathrm{C}$. $I_{\mathrm{K}}$ amplitudes were measured at a point $60 \mathrm{msec}$ after the onset of the voltage step. Percentage attenuation measures were a comparison of $I_{\mathrm{K}}$ amplitudes determined immediately prior to, and $15 \mathrm{~min}$ following, application of the test compounds.

\section{Drugs}

Protonated forms of the fatty acids oleate and methyloleate (Sigma) were dispersed in external saline by vigorous vortex mixing and ultrasonication. The active $(4-\beta)$ and inactive $(4-\alpha)$ forms of phorbol-12,13dibutyrate (PDB; LC Services, Woburn, MA) and the protein kinase C inhibitors RO-31-8220 (a gift of Dr. G. Lawton, Roche Products Ltd., Welwyn Garden City, UK), calphostin C (Kamiya Biomedical Co., Thousand Oaks, CA), and staurosporin (Boehringer Mannheim) were prepared as stock solutions in $10 \%$ dimethyl sulfoxide before their addition to external saline.

All drugs were applied by switching the bath solution to one containing the drug at a point upstream from the bath chamber. In the cases where a PKC inhibitor was used together with a PKC activator, the inhibitor was introduced into the bath 5 min prior to the activator and remained in the bath for the duration of the experiment.

\section{Results}

Cercbella from embryonic Sprague-Dawley rats (E19-E21) were dissected, dissociated with trypsin, and cultured in high-K MEM for 12-22 d. Initially, we sought to determine if the distribution of PKC isozymes reported in sections of the adult rat cerebellum would be preserved in tissue culture. To this end, we used polyclonal antisera directed against PKC-I, -II, and -III with standard immunocytochemical techniques. As it is not always possible to identify cell type in a mixed culture based on morphological criteria alone, we also employed antisera directed against calbindin- $\mathrm{D}_{28 \mathrm{~K}}$ (Thomasset et al., 1984), a marker shown to recognize Purkinje cells selectively in sections of adult rat cerebellum.

Figure $1 a$ illustrates the localization of PKC-I immunoreactivity in a large cell with a complex arborization (a presumptive Purkinje cell), and the absence of PKC-I immunoreactivity in small, round, clustering cells (presumptive granule cells). Double labeling for PKC-I and calbindin- $\mathrm{D}_{28 \mathrm{~K}}$ shows immunoreactivity for this isozyme and this Purkinje cell marker to be colocalized in a presumptive Purkinje cell. (Fig. 1d.e). In marked contrast, PKC-II immunoreactivity may be clearly seen in presumptive granule cells (Fig. $1 b$ ). This distribution corresponds to that observed in sections of rat (Ase et al., 1988; Hashimoto et al., 1988; Huang et al., 1988, 1990; Kose et al., 1988; Saito 

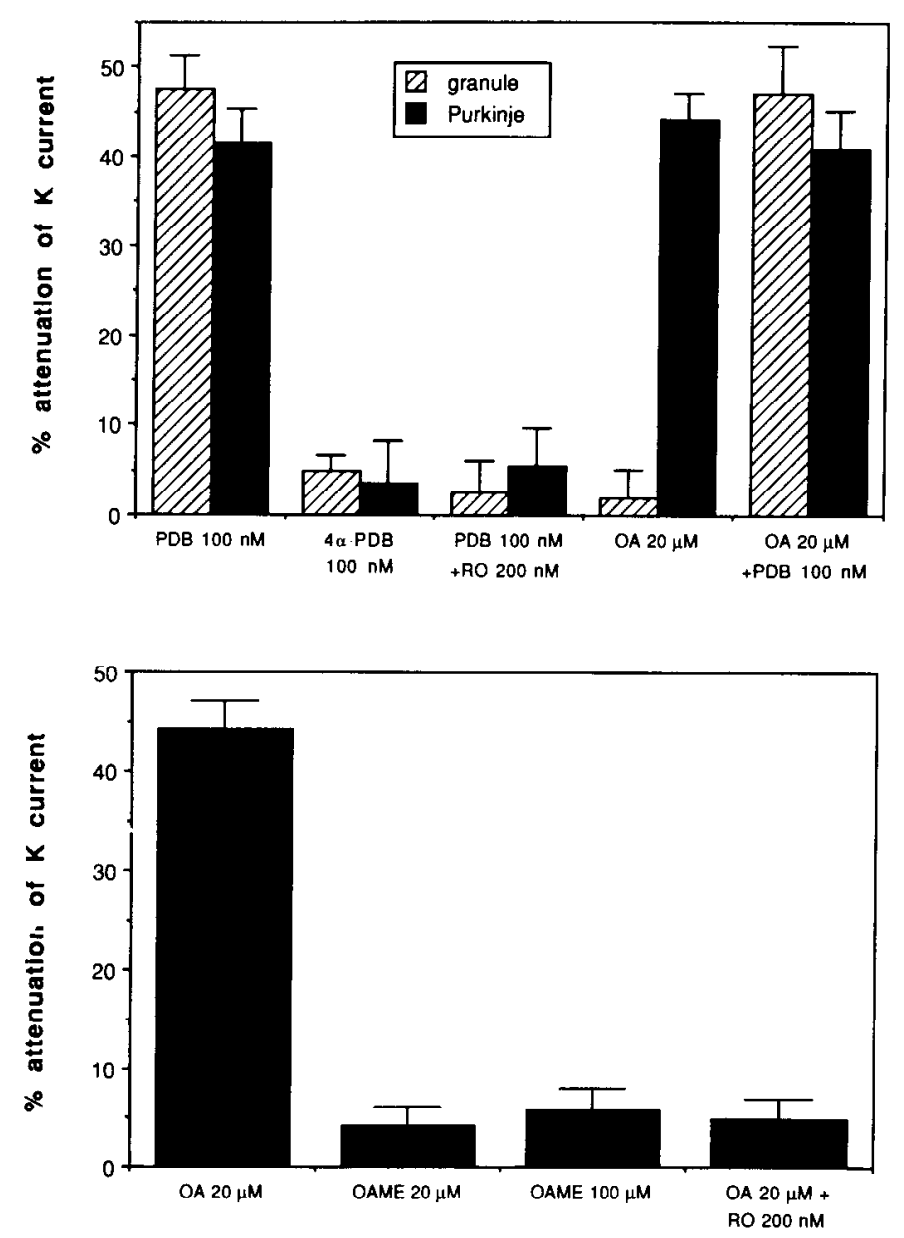

Figure 4. Experiments to determine if attenuation of $I_{\mathrm{K}}$ by c-UFA and PE are produced by PKC activation. Top, The attenuation of $I_{\mathrm{K}}$ produced by PE in both granule and Purkinje cells is not produced by application of an incrt PE $(4 \alpha-P D B)$ and is blocked by coapplication of RO-31-8220 ( $R O)$, a PKC inhibitor. Application of PE and c-UFA together did not produce an additive effect on $I_{\mathrm{K}}$ attenuation in either cell type. Bottom, Attenuation of $I_{\mathrm{K}}$ produced in Purkinje cells by a cUFA is not produced by an inert c-UFA, OAME, and is blocked by coapplication of RO-31-8220 (RO). Each bar represents the mean \pm SD of six separate observations.

et al., 1988) or rabbit (Hidaka et al., 1988) cerebellum. PKCIII immunoreactivity was very weak in all neuronal cell types, but was present in glia (Fig. 1c).

The main finding of the study is shown in Figure 2: outward current, evoked by a step from $-30 \mathrm{mV}$ to $+30 \mathrm{mV}$ in TTXcontaining, nominally $\mathrm{Ca}^{2+}$-free saline, was attenuated in Purkinje cells by both a PE (PDB) and a c-UFA (OA), but only by $\mathrm{PE}$ in granule cells. Thus, the distribution of the PKC-I isozyme predicts the response of the neurons to these two different modes of PKC activation. The attenuation produced by both $\mathrm{PE}$ and c-UFA took the form of a simple decrease in total conductance, as indicated by a reduction in the slope of the current-voltage relation (Fig. 3). In contrast, we saw no evidence for an alteration in the voltage dependence of activation. When the experiments illustrated in Figures 2 and 3 were repeated using external saline containing $200 \mathrm{mM}$ EGTA to buffer trace $\mathrm{Ca}^{2+}$, no differences were seen in any of the following measures: the percentage attenuation by the activators, the current-voltage relation, or the shape or amplitude of the evoked current (data not shown). Under these conditions, $\mathrm{Na}$ and $\mathrm{Ca}$ currents, as well as $I_{\mathrm{K}(\mathrm{Ca})}$ and $I_{A}$, should be absent, leaving predominantly delayed rectifier current, $I_{\mathrm{K}}$.

Recordings were routinely made using the perforated-patch technique (Horn and Marty, 1987), in which electrical continuity between the recording pipette solution and the cytoplasm is achieved by the incorporation of nystatin molecules into the membrane patch. The nystatin molecules form voltage-insensitive pores that are selective for small, monovalent ions. Consequently, the molecular machinery of second messenger signaling and calcium buffering remains relatively undisturbed. This is particularly relevant in the present case, as the PKC-I isozyme is reported to be $\sim 90 \%$ cytosolic (Shearmen et al., 1989a) and hence susceptible to washout in conventional wholecell recording. An examination of the effects of PKC activators on $I_{\mathrm{K}}$ measurcd in Purkinje cclls using conventional whole-cell recording techniques showed that the attenuation produced by both PE and c-UFA was smaller in this case. C-UFA $(20 \mu \mathrm{M}$ oleate) produced a $44.2 \pm 3.0 \%$ (mean $\pm \mathrm{SD} ; n=6)$ attenuation of $I_{\mathrm{K}}$ measured with perforated patch and a $19.8 \pm 3.7 \%(n=$ $5)$ attenuation measured with conventional whole-cell recording. Similarly, PE (100 nM PDB) produced a $41.3 \pm 4.2 \%(n=$ 6) attenuation with perforated patch and a $23.6 \pm 4.8 \%(n=5)$ attenuation with conventional whole-cell recording. The elapsed time between the formation of the gigaseal and the application of the PKC activator was the same for both recording methods, $\sim 20 \mathrm{~min}$.

Experiments to determine if the effects of PE and c-UFA on $I_{\mathrm{K}}$ were mediated by $\mathrm{PKC}$ activation are shown in Figure 4. Only minimal attenuation of $I_{\mathrm{K}}$ was observed with application of $4 \alpha$-PDB, a PE inert with respect to PKC activation. Likewise, preincubation of the cclls in RO-31-8220, a PKC inhibitor (Davis et al., 1989; Linden and Connor, 1991), almost entirely blocked the PE effect on $I_{\mathrm{K}}$. A similar blockade was produced by the PKC inhibitor calphostin C applied at $2.0 \mu \mathrm{M}$ (Kobayashi et al., 1989) or the nonspecific protein kinase inhibitor staurosporin applied at $20 \mathrm{nM}$ (Tamaoki et al., 1986; data not shown). OA methyl ester (OAME) is a compound that does not activate PKC (Murakami and Routtenberg, 1985), but that shares many of the physical properties of $\mathrm{OA}$, including the ability to fluidize membranes (see Linden and Routtenberg, 1989b, for a complete discussion of control procedures for PKC-activating fatty acids). Application of OAME produced only minimal attenuation of $I_{\mathrm{K}}$ in Purkinje cells. Preincubation of Purkinje cells in RO-318220 also blocked the c-UFA effect. Finally, if c-UFA and PE are both producing their effects on Purkinje cells through activation of PKC-I, then one would expect that application of these two compounds together would produce a nonadditive attenuation of $I_{\mathrm{K}}$. This notion was confirmed in the present experiments (Fig. 4, top).

\section{Discussion}

These observations indicate that the effects of PE and c-UFA in the present study are mediated by PKC activation. However, it has been reported that the attenuation of voltage-gated $\mathrm{Ca}$ currents in chick dorsal root ganglion cells by $P E$ or DAG results from a direct interaction with a site on the outside of the cell membrane, in a manner independent of PKC activation (Hockberger et al., 1989a). A similar mechanism is unlikely to be operative in the present case, as inactive PE or c-UFA produced $<6 \%$ attenuation of $I_{\mathrm{K}}$ (Fig. 4). In addition, any PKC-independent mechanism would have to explain the differential effects produced by PE and c-UFA in granule and Purkinje cells. 
The present results suggest that the presence of PKC-I in Purkinje cells confers upon them the ability to respond electrophysiologically to c-UFA and, by extension, to activating factors that will not affect granule cells. Specific functions of the PKC-I isozyme remain largely unknown. However, certain roles are suggested by its localization. PKC-I appears to be localized exclusively in the CNS (Shearman et al., 1988). Within the CNS, it is most enriched in the cerebellar cortex (Purkinje cells), hippocampal formation (pyramidal and dentate gyrus granule cells), amygdala, and neocortex (Ase et al., 1988; Hashimoto et al., 1988; Huang et al., 1988; Kose et al., 1988; Saito et al., 1988), areas known to exhibit various forms of use-dependent synaptic plasticity. A striking gradient of increasing PKC-I (but not PKCII or -III) expression may be seen along the occipital-temporallimbic visual processing pathway of the monkey (Huang el al., 1989), which correlates positively with the importance of these regions in storage of visual information, as determined in behavioral studies (Mishkin, 1982; Murray and Mishkin, 1986). Thus, it is tempting to speculate that PKC-I is somehow involved in information storage.

A model of information storage has been demonstrated in Purkinje cells in which coactivation of climbing fiber and parallel fiber inputs to the Purkinje cell leads to a long-term depression (LTD) of the parallel fiber input (Ito et al., 1982; Ito, 1989). Cerebellar LTD is thought to be mediated postsynaptically, as it may also be demonstrated as a depression of the Purkinje cell response to iontophoretically applied glutamate or AMPA (Ito et al., 1982; Kano and Kato, 1987; Crepel and Krupa, 1988; Linden and Connor, 1991; Linden et al., 1991) but not aspartate or NMDA (Crepel and Krupa, 1988; Linden and Connor, 1991). It has been suggested that PKC activation is necessary for LTD induction because PKC inhibitors have been shown to block this phenomenon (Linden and Connor, 1991) while PE application induces a similar depression (Crepel and Krupa, 1988; Crepel and Jaillard, 1991; Linden and Connor, 1991). The presence of strong PKC-I immunoreactivity in Purkinje cell dendritic cytoplasm as revealed by electron microscopy (Kose et al., 1988) is consistent with this notion.

The observation that the distribution of PKC isozymes in sections of adult rat ccrebcllum was prescrved in a culture of embryonic tissue is interesting, but not easily interpretable. It might indicate that the cell type-specific expression of PKC isozymes is already determined by E19-E21. Alternatively, this pattern of isozyme expression might require certain signals during postnatal development (synaptic input, growth, or differentiation factors) that are also present in our cell-culture conditions. A developmental study of PKC isozyme expression in rat cerebellum (Huang et al., 1990) showed PKC-I immunoreactivity restricted to Purkinje cells, with an abrupt increase between the second and third postnatal weeks, corresponding to the development of the Purkinje cell dendritic arbor and the arrival of parallel fiber input. PKC-II immunoreactivity was seen in granule cell precursors in the external granular layer of 1-week-old rats, and appeared to track the migration of granule cells to the internal granular layer during the following 2 weeks of development. PKC-I immunorcactivity did not occur in granule cells or their identifiable precursors at any postnatal stage. Likewise, PKC-II immunoreactivity did not occur in Purkinje cells during postnatal development, suggesting that the distribution of these PKC isozymes is determined before birth in rat cerebellum.

The main finding of this study, that the distribution of PKC-I predicts the response of Purkinje and granule cells to c-UFA and $\mathrm{PE}$, is important in that it provides a bridge between a purely anatomical observation, the differential distribution of PKC isozymes among cell types, and a well-known architect of neuron electrical signaling, the delayed outward rectifier current, $I_{\mathrm{K}}$. A more inclusive issue, determining the net effect of c-UFA application on Purkinje cell electrical function, awaits further study. $\Lambda$ s previous work has shown c-UFA-induced PKC activation to attenuate voltage-gated $\mathrm{Na}$ and $\mathrm{Ca}$ currents (Linden and Routtenberg, 1989b; Keyser and Alger, 1990) as well as K currents, the total effect of c-UFA is likely to be complex.

\section{References}

Apkon M, Nerbonne JM (1988) $\alpha-1$ adrenergic agonists selectively suppress voltage-dependent $\mathrm{K}^{+}$currents in rat ventricular myocytes. Proc Natl Acad Sci USA 85:8756-8760.

Ase K, Saito N, Shearman MS, Kikkawa U, Ono Y, Igarashi K, Tanaka C, Nishizuka Y (1988) Distinct cellular expression of $\beta \mathrm{l}$ and $\beta \mathrm{II}$ subspecies of protein kinase $C$ in rat cerebellum. J Neurosci 8:38503856.

Baraban JM, Snyder SH, Alger BE (1985) Protein kinase C regulates ionic conductance in hippocampal pyramidal neurons: electrophysiological effects of phorbol esters. Proc Natl Acad Sci USA 82:25382542.

Brandt SJ, Niedel JE, Bell RM, Young WS III (1987) Distinct patterns of expression of different protein kinase $C$ mRNAs in rat tissues. Cell $49: 57-63$

Colby KA, Blaustein MP (1988) Inhibition of voltage-gated K channels in synaptosomes by $s n-1,2$-dioctanoylglycerol, an activator of protein kinase C. J Neurosci 8:4685-4692.

Coussens L, Parker PJ, Rhee L, Yang-feng TL, Chen E, Waterfield MD, Francke U, Ullrich A (1986) Multiple, distinct forms of bovine and human protein kinase $\mathrm{C}$ suggest diversity in cellular signalling pathways. Science 233:859-866.

Crepel F, Jaillard D (1991) Pairing of pre- and postsynaptic activities in cerebellar Purkinje cells induces long-term changes in synaptic efficacy in vitro. J Physiol (Lond) 432:123-141.

Crepel F, Krupa M (1988) Activation of protein kinase $C$ induces a long-term depression of glutamate sensitivity of cerebellar Purkinje cells. An in vitro study. Brain Res 458:397-401.

Davis PD, Hill CH, Keech E, Lawton G, Nixon JS, Sedgwick AD, Wadsworth J, Westmacott D, Wilkinson SE (1989) Potent selective inhibitors of protein kinase C. FEBS Lett 259:61-63.

Doerner D, Pitler TA, Alger BE (1988) Protein kinase C activators block specific calcium and potassium current components in isolated hippocampal neurons. J Neurosci 8:4069-4078.

Farley J, Auerbach S (1986) Protein kinase C activation induces conduclance changes in Hermissenda photoreceptors like those seen in associative learning. Nature 319:220-223.

Grega DS, Werz MA, Macdonald RL (1987) Forskolin and phorbol esters reduce the same potassium conductance of mouse neurons in culture. Science 235:345-348.

Hashimoto T, Ase K, Sawamura S, Kikkawa U, Saito N, Tanaka C, Nishizuka Y (1988) Postnatal development of a brain-specific subspecies of protein kinase $C$ in rat. J Neurosci 8:1678-1683.

Hidaka $\mathbf{H}$, Tanaka $T$, Onoda $\mathbf{K}$, Hagiwara $\mathbf{M}$, Watanabe $\mathbf{M}$, Ohta $\mathbf{H}$, Ito $Y$, Tsurudome M, Yoshida T (1988) Cell type-specific expression of protein kinase $\mathrm{C}$ isozymes in the rabbit cerebellum. J Biol Chem 263:4523-4526.

Higashida H, Brown DA (1986) Two polyphosphatidylinositide metabolites control two $\mathrm{K}^{+}$currents in a neuronal cell. Nature 323:333335.

Hockberger P, Toselli M, Swandulla D, Lux HD (1989a) A diacylglycerol analogue reduces neuronal calcium currents independently of protein kinase C activation. Nature 338:340-342.

Hockberger PE, Tseng H-Y, Connor JA (1989b) Development of rat cerebellar Purkinje cells: electrophysiological properties following acute isolation and in long-term culture. J Neurosci 9:2258-2271.

Horn R, Marty A (1987) Muscarinic activation of ionic currents measured by a new whole-cell recording method. J Gen Physiol 92:145158.

Huang FL, Yoshida Y, Nakabayashi H, Young WS III, Huang K-P 
(1988) Immunocytochemical localization of protein kinase $\mathrm{C}$ isozymes in rat brain. J Neurosci 8:4734-4744.

Huang FL, Yoshida Y, Nakabayashi H, Friedman DP, Ungerleider LG, Young WS III, Huang K-P (1989) Type I protein kinase C isozymes in the visual information-processing pathway of monkey brain. J Cell Biochem 39:401-410.

Huang FL, Young WS III, Yoshida Y, Huang K-P (1990) Developmental expression of protein kinase $\mathrm{C}$ isozymes in rat cerebellum. Dev Brain Res 52:121-130.

Ito M (1989) Long-term depression. Annu Rev Neurosci 12:85-102.

Ito $M$, Sakurai M, Tongroach P (1982) Climbing fibre induced depression of both mossy fibre responsiveness and glutamate sensitivity of cerebellar Purkinje cells. J Physiol (Lond) 324:113-134.

Kano M, Kato M (1987) Quisqualate receptors are specifically involved in cerebellar synaptic plasticity. Nature 325:276-279.

Keyser DO, Alger BE (1990) Arachidonic acid modulates hippocampal calcium current via protein kinase $C$ and oxygen radicals. Neuron 5: 545-553.

Kikkawa U, Takai Y, Minakuchi R, Inohara S, Nishizuka Y (1982) Calcium-activated phospholipid-dependent protein kinase from rat brain. J Biol Chem 257:13341-13348.

Knopf JL, Lee M-H, Sultzman LA, Kriz RW, Loomis CR, Hewick RM, Bell RM (1986) Cloning and expression of multiple protein kinase C cDNAs. Cell 46:491-502.

Kobayashi E, Nakano H, Morimoto M, Tamaoki T (1989) Calphostin $\mathrm{C}(\mathrm{UCN}-1028 \mathrm{C})$, a novel microbial compound, is a highly potent and specific inhibitor of protein kinase C. Biochem Biophys Res Commun 159:548-553.

Kose A, Saito N, Ito H, Kikkawa U, Nishizuka Y, Tanaka C (1988) Electron microscopic localization of type I protein kinase $\mathrm{C}$ in rat Purkinje cells. J Neurosci 8:4262-4268.

Linden DJ, Connor JA (1991) Participation of postsynaptic PKC in cerebellar long-term depression in culture. Science 254:1656-1659.

Linden DJ, Routtenberg A (1989a) The role of protein kinase C in long-term potentiation: a testable model. Brain Res Rev 14:279-296.

Linden DJ, Routtenberg A (1989b) Cis-fatty acids, which activate protein kinase $\mathrm{C}$, attenuate $\mathrm{Na}^{+}$and $\mathrm{Ca}^{2+}$ currents in mouse neuroblastoma cells. J Physiol (Lond) 419:95-119.

Linden DJ, Dickinson MH, Smeyne M, Connor JA (1991) A longterm depression of AMPA currents in cultured cerebellar Purkinje neurons. Neuron 7:81-89.

Malenka RC, Madison DV, Andrade R, Nicoll RA (1986) Phorbol esters mimic some cholinergic actions in hippocampal pyramidal neurons. J Neurosci 6:475-480.

Malinow R, Schulman H, Tsien RW (1989) Inhibition of postsynaptic PKC or CaMKII blocks induction but not expression of LTP. Science 245:862-866.

McPhail LC, Clayton CC, Snyderman R (1984) A potential second messenger role for unsaturated fatty acids: activation of $\mathrm{Ca}^{2+}$-dependent protein kinase. Science 224:622-625.

Mishkin M (1982) A memory system in the monkey. Philos Trans R Soc Lond [Biol] 298:85-95.

Murakami K, Routtenberg A (1985) Direct activation of purified protein kinase $C$ by unsaturated fatty acids (oleate and arachidonate) in the absence of phospholipids and $\mathrm{Ca}^{2+}$. FEBS Lett 192:189-193.
Murakami K, Chan SY, Routtenberg A (1986) Protein kinase C activation by cis-unsaturated fatty acid in the absence of $\mathrm{Ca}^{2+}$ and phospholipid. J Biol Chem 261:15424-15429.

Murray EA, Mishkin M (1986) Visual recognition in monkeys following rhinal cortical ablations combined with either amygdalectomy or hippocampectomy. J Neurosci 6:1991-2003.

Nccdlcman P, Turk J, Jakschick BA, Morrison AR, Lefkowitz JB (1986) Arachidonic acid metabolism. Annu Rev Biochem 55:69-102.

Nishizuka Y (1988) The molecular heterogeneity of protein kinase C and its implications for cellular regulation. Nature 334:661-665.

Olds JL, Anderson ML, McPhie DL, Staten LD, Alkon DL (1989) Imaging of memory-specific changes in the distribution of protein kinase $\mathrm{C}$ in the hippocampus. Science 245:866-869.

Ono Y, Fujii T, Ogita K, Kikkawa U, Igarishi K, Nishinuka Y (1987) Identification of three additional members of rat protein kinase $\mathrm{C}$ family. FEBS Lett 226:125-128.

Romijn H, Habets A, Mud M, Walters P (1982) Nerve outgrowth, synaptogenesis and bioelectric activity in fetal rat cerebral cortical tissue cultured in serum-free, chemically defined medium. Dev Brain Res 2:583-589.

Saito N, Kikkawa U, Nishizuka Y, Tanaka C (1988) Distribution of protein kinase C-like immunoreactive neurons in rat brain. J Neurosci 8:369-382.

Sawada M, Ichinose M, Maeno T (1989) Protein kinase C activators reduce the inositol triphosphate-induced outward current and the $\mathrm{Ca}^{2+}$ activated outward current in identified neurons of Aplysia. J Neurosci Res 22:158-166.

Shearman MS, Kokoka Y, Ase K, Kikkawa U, Nishizuka Y (1988) Type I $(\gamma)$ protein kinase $C$ subspecies appears to be located exclusively in central nervous tissues. Biochem Soc Trans 16:307-308.

Shearman MS, Naor Z, Sekiguchi K, Kishimoto A, Nishizuka Y (1989a) Selective activation of the $\gamma$-subspecies of protein kinase $C$ from bovine cerebellum by arachidonic acid and its lipoxygenase metabolites. FEBS Lett 243:177-182.

Shearman MS, Sekiguchi K, Nishizuka Y (1989b) Modulation of ion channel activity: a key function of the protein kinase Cenzyme family. Pharmacol Rev 41:211-237.

Shimohama S, Saitoh T, Gage FH (1990) Differential expression of protein kinase $\mathrm{C}$ isozymes in rat cerebellum. $\mathrm{J}$ Chem Neuroanat 3 367-375.

Tamaoki T, Nomoto H, Takahashi I, Kato Y, Morimoto M, Tomita F (1986) Staurosporine: a potent inhibitor of phospholipid/ $\mathrm{Ca}^{2+} \mathrm{de}$ pendent protein kinase. Biochem Biophys Res Commun 135:397402.

Thomasset M, Rabie A, Parkes CO, Desplan C, Hanin D, CuisinierGleizes P (1984) Vitamin D-dependent calcium-binding protein in the cerebellum: a marker of the Purkinje cell development. Dev Pharmacol Ther 7:6-11.

Wolfe (1982) Eicosanoids: prostaglandins, thromboxanes, leukotrienes, and other derivatives of carbon-20 unsaturated fatty acids. J Neurochem 38:1-14.

Young WS III (1988) Expression of three (and a putative four) protein kinase $C$ genes in brains of rat and rabbit. J Chem Neuroanat 1:177194. 